\title{
Perancangan Buku Interaktif Belajar Baca Tulis bagi Orangtua Anak Penderita Disleksia di Surabaya
}

\author{
Atalya Sharon Jerusha Turangan ${ }^{1}$, Wibowo ${ }^{2}$, Rika Febriani ${ }^{3}$ \\ Program Studi Desain Komunikasi Visual, \\ Fakultas Seni dan Desain, Universitas Kristen Petra \\ punyasharon@gmail.com
}

\begin{abstract}
This educational media is made for helping the literacy learning process for Dyslexics in Surabaya. This undergraduate thesis needs to be done because the number of available educative media for dyslexics is very low.

Methods being used are qualitative methods. Those methods are observation, interview, and literal studies. One of the most effective methods for dyslexics to learn literacy is multisensory method. That's why, this multisensory based undergraduate thesis is made for the parents to help their dyslexic child learn literacy.

This undergraduate thesis suggests an approach where parents acts as a teacher for their children. Besides being a teacher, parents can also act as the one who give moral support to the children.

Perancangan dibuat dengan dasar orangtua sebagai pengajar karena kebutuhan pembelajaran yang panjang dan intens. Selain itu orangtua juga bisa menjadi sosok yang dapat memberikan pembelajaran teknis sekaligus dukungan moral.
\end{abstract}

Keywords: Dyslexia, Literacy studies, Parent and children

\section{PENDAHULUAN}

Disleksia adalah adalah salah satu jenis gangguan atau kesulitan belajar yang umumnya mempengaruhi kemampuan membaca serta pengejaan seseorang. Penderita disleksia tidak hanya mengalami kesulitan dalam membaca, tapi juga dalam hal penyusunan sistematis, ingatan jangka pendek, dan beberapa aspek lain.

Disleksia adalah keadaan yang kronis dan tetap dari sejak kecil hingga dewasa. Karena itu, penanganan harus dilakukan sejak dini. Secara umum, anak mulai belajar membaca pada usia 4-5 tahun. (Zulhaqi,
2013). Namun tidak jarang seorang anak penderita disleksia yang kesulitan belajar baru berhasil menguasai kemampuan baca-tulis pada usia 8 tahun. Sangatlah penting bagi anak penderita disleksia untuk belajar metode baca-tulis yang tepat untuk diri sendiri agar dapat berbahasa dengan baik hingga dewasa.

Gejala disleksia di masa kanak-kanak yang nampak menghilang seiring berjalannya waktu bukanlah karena disleksia telah sembuh. Gejala disleksia tampak menghilang karena individu tersebut berhasil menemukan solusi untuk mengatasi kesulitan yang diakibatkan oleh disleksia. Meskipun tidak 
dapat disembuhkan, penderita disleksia dapat belajar untuk menemukan solusi metode pembelajaran yang cocok untuk mereka. (Pertiwi, 2016).

\section{Menurut kepala Asosiasi Disleksia} Indonesia Riyani T Bondan, kurang lebih 1015\% anak-anak Indonesia adalah penderita disleksia. (Permanasari, 2010). Selain itu, kepala Dyslexia Parents Supports Group Dr. Ursula Yudith berkata bahwa ada banyak penderita disleksia di kota Surabaya walaupun tidak disadari oleh lingkungan sekitarnya. (Surya, 2016).

Dr. Kristiantini Dewi juga menambahkan bahwa anak-anak penderita disleksia sering kali menjadi korban bullying teman sekelas karena tidak dapat mengikuti pelajaran. Penderita biasanya dianggap bodoh dan tidak normal. Bullying ini sendiri dapat memberikan efek buruk bagi kepercayaan diri, sehingga menghambat proses belajar mereka. Ditambah lagi, karena keberadaannya yang tidak dikenal luas di Indonesia, guru dan orang tua penderita disleksia sering kali kewalahan dalam mengajari mereka ilmu baca tulis yang sederhana. Bagi orang tua penderita, disleksia dapat mendatangkan kekecewaan dan rasa khawatir. Dalam Yale Center for Dyslexia \& Creativity, Joshua Henkins menghimbau orang tua sebagai sosok terdekat harus mengerti cara-cara yang terbaik untuk mengajar anak mereka. Kerja sama yang seimbang antar guru dan orang tua akan sangat membantu anak penderita disleksia belajar dengan lebih baik.

Pada bulan Juli 2016 ini, pemerintah kota Surabaya bekerja sama dengan berbagai ahli disleksia Indonesia mengenalkan Dyslexia Corner di perpustakaan umum Kota Surabaya. Di sudut perpustakaan kota ini, tersedia komputer yang dilengkapi dengan aplikasi interaktif bernama Lexipal. (Tempo, 2016). Lexipal dibuat dengan tujuan memberikan pengertian mengenai disleksia bagi masyarakat dan terapi remedial bagi penderita disleksia sendiri. (Suara Surabaya, 2016). Konten dari Lexipal sendiri mencakup permainan bentuk dan pola; persamaan, perbedaan, dan perbandingan; ingatan jangka pendek; asosiasi obyek; persepsi arah; urutan aktivitas; pemahaman tempat; konsep waktu; keterampilan sosial; huruf; suku kata dan kata; serta kalimat sederhana.

Untuk menyikapi penyakit disleksia, media yang digunakan pemerintah bisa dibilang baru dan inovatif. Namun sayangnya, media ini jauh dari jangkauan rumah penderita disleksia. Disamping kontennya yang luas dan variatif, Lexipal masih jauh dari keseharian penderita. 
Penderita disleksia membutuhkan metode pembelajaran khusus jangka panjang. Beberapa metode seperti pembelajaran multisensori, metode fonik (bunyi), dan metode linguistik dapat membantu penderita disleksia untuk belajar dengan baik. (Vitriani Sumiartis, 2010). Seperti anak-anak pada umumnya, anak-anak penderita disleksia pun tidak dapat belajar membaca sendiri. Hanya menyerahkan $100 \%$ pembelajaran baca tulis anak di sekolah pun bukan pilihan yang bijak. Sangatlah penting bagi orang tua untuk mengerti metode terbaik untuk belajar baca tulis di rumah. (Joshua Jenkins, 2016).

Sebelum sampai di tahap pembelajaran baca tulis pun, orang tua memegang peranan utama untuk memberikan pengertian dan dukungan moral. Penderita disleksia akan mengalami proses yang sulit selama ia bersekolah. Mereka sangat membutuhkan pegangan dan support yang kuat dari orang tau. Karena itu, dibutuhkan sebuah media seperti buku interaktif dan permainan yang bisa dipergunakan orang tua untuk mengajar kemampuan baca tulis kepada penderita disleksia di rumah, serta dapat mencakup metode-metode pembelajaran yang diperlukan.

Penelitan dan pembelajaran metode belajar bagi penderita disleksia memang sudah ada. Sebuah buku berjudul Overcoming
Dyslexia karya Sally Shaywitz, M.D. adalah contoh karya yang baik mengenai penanganan Disleksia. Buku ini berisi berbagai metode yang dapat dilakukan oleh orang tua, guru, ataupun penderita Disleksia sendiri untuk belajar baca tulis. Selain metode, buku ini juga berisi berbagai soal latihan yang dapat dilakukan setiap malam oleh penderita. Namun sayangnya, buku ini berbasis bahasa Inggris. Selain itu, buku ini juga tidak menyediakan permainan interaktif yang dapat dipakai bersama antar orang tua dan anak penderita. Buku interaktif yang dibuat akan berbasis bahasa dan budaya Indonesia. Dengan menggunakan budaya dan kondisi lingkungan yang familiar bagi penderita, diharapkan pembelajaran dari buku interaktif dapat membantu.

\section{TEORI PENUNJANG}

\section{Buku Interaktif}

Buku interaktif adalah sub-genre di buku anak yang memerlukan partisipasi dari pembaca. Partisipasi aktif dari pembaca dibutuhkan untuk memahami isi buku. Buku interaktif juga mencakup jenis-jenis buku yang melibatkan teknologi modern ataupun buku terkomputerisasi. Buku interaktif terdiri dari unsur-unsur berikut; 


\section{Ilustrasi}

Ilustrasi adalah hasil karya seni yang berfungsi untuk menjabarkan, menjelaskan, menafsirkan, ataupun mendekorasi sebuah teks (Bodmer, 1992, p. 72). Ilustrasi sendiri sudah dipakai secara luas dalam bidang poster, periklanan, buku komik, seni animasi, kartu ucapan, dan lainnya

\section{Tipografi}

Menurut Wijaya (n.d.), tipografi dapat dikatakan sebagai visual language atau bahasa yang dapat dilihat. Tipografi adalah salah satu sarana untuk menterjemahkan kata-kata yang terucap ke halaman yang dapat dibaca. Fungsi utama dari tipografi ialah mengkomunikasikan ide secara langsung kepada pengamat. Namun tidak sekedar itu, pengerjaan tipografi yang tidak didekorasi ataupun tidak sesuai dengan desain tidak akan bisa mengkomunikasikan pesan dengan baik. Dengan kata lain, selain memiliki fungsi komunikatif utama, tipografi juga memiliki fungsi estetis.

Pengertian tipografi ialah ilmu yang mempelajari bentuk huruf, dimana huruf, angka, tanda baca, dan sebagainya tidak hanya dilihat sebagai simbol dari suara, tetapi terutama dilihat sebagai suatu bentuk desain.

\section{Warna}

Warna adalah elemen yang menambahkan dimensi yang baru pada komunikasi. Warna juga menjadi elemen yang dapat menambahkan ekspresi, mood, dan emosi pada suatu desain.

Dalam penggunaan warna, tidak ada aturan yang tetap ataupun pasti. Namun dalam setiap penempatan dan penggunaannya, warna dapat memberikan pengaruh tertentu pada pembaca. Namun pengaruh yang diberikan juga bergantung pada konteks desain, budaya pembaca, kondisi pencahayaan, dan lain-lain (Gordon \& Gordon. 2010, p. 44).

Menurut wawancara yang sudah dilakukan pada Nindia Pratitis, dosen psikologi Universitas 17 Agustus Surabaya, sering kali penderita mengalami kebingungan untuk menenetukan urutan bacaan dari suatu kalimat. Karenanya, sebaiknya warna-warni yang cerah dan kontras diberikan pada tiap kata agar mudah dibedakan dan diingat.

\section{Layout}

Layout adalah proses desain yang mengatur format halaman dan margin sebagai komponen utama. Proses pengerjaan layout melibatkan produk desain 2 dimensi dan 3 dimensi. 
Dalam proses pengerjaanya, pengertian hirarki visual sangatlah diperlukan. Hirarki visual ialah urutan atau alur visual yang dibuat agar diikuti oleh pembaca. Sebagian besar karya layout memiliki komponenkomponen seperti headline, ilustrasi, body copy, dan sebagainya. Tujuan dari hirarki visual adalah mengatur penempatan komponen-komponen ini agar memiliki alur urutan yang sesuai untuk dibaca oleh pembaca (Gordon \& Gordon, 2010, p. 38).

Menurut Pratitis, penderita disleksia memerlukan sistem belajar yang jelas dan sederhana. Untuk itu, pemakaian layout yang sederhana dan mudah diikuti sangatlah baik bagi penderita.

\section{Pembelajaran Multi-Sensori}

Pembelajaran multi-sensori ialah pembelajaran yang melibatkan lebih dari satu indera. Pembelajaran multi-sensori ialah metode paling efektif bagi anak-anak yang mengalami gangguan membaca. Ada beberapa contoh teknik pembelajaran yang bisa dilakukan oleh orang tua dan anak. Penggunaan teknik-teknik berikut dapat dilakukan secara bergantian agar anak dapat menikmati variasi. Namun hasil pembelajaran akan menjadi lebih baik apabila teknik yang dipakai sesuai dengan gaya belajar ataupun indra belajar terkuat anak. Gaya belajar tersebut ialah Teknik visual, pendengaran, peraba, dan kinestetik.

\section{Baca Tulis}

Membaca adalah melihat serta memahami isi dari apa yang tertulis. Sedangkan menulis adalah membuat huruf (angka dan sebagainya) dengan pena (Pusat Bahasa Departemen Pendidikan Nasional Republik Indonesia).

Tidak seperti bicara, membaca dan menulis adalah kemampuan yang harus dipelajari. Seseorang harus mengembangkan pemahaman mengenai huruf tertulis yang mewakili bunyi lisan. Berbicara sendiri ialah proses automatis bawah sadar yang dijalankan oleh modul fonologis otak secara biologis. Sebaliknya, membaca harus melewati proses berikut:

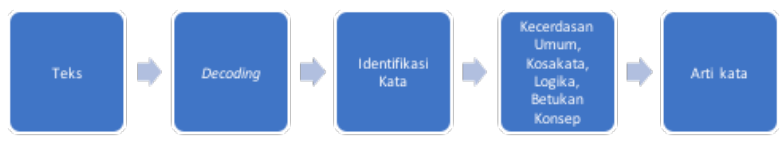

Gambar 1 Proses Membaca Sumber: https://dyslexia.yale.edu

Pada grafik di atas, decoding ialah proses pemecahan kata menjadi elemenelemen fonimnya. Fonim sendiri ialah sekmen terkecil bahasa yang sering kali dipelajari ketika anak usia dini mengeja sebuah kata. Anak-anak usia dini pada 
umumnya mulai memahami konsep fonim pada usia 4 hingga 6 tahun.

Ketika seorang anak sudah bisa melewati proses-proses membaca tersebut, ia dapat belajar mengenai hal-hal baru dengan menyimpan informasi untuk dipakai pada masa yang akan datang. Proses pembelajaran membaca yang cukup akan menghasilkan data kosa kata yang semakin luas. Sebagai contoh, Informasi ini kemudian dapat dipakai ketika hendak menulis, dimana bentukan huruf dan arti kata yang sudah dipahami dituangkan dalam bentuk tulisan. Umumnya, anak-anak memahami dasar-dasar membaca di saat yang sama mereka belajar menulis (Shaywitz, 1996).

- Menulis dan membaca sendiri tidak dapat berdiri sendiri. Keduanya memfasilitasi satu sama lain. Gangguan membaca ialah tanda dari gangguan menulis bagi anak. Namun pada umumnya, anak-anak akan menguasai kemampuan membaca lebih dulu daripada menulis. Menulis sendiri bukanlah kemampuan yang sederhana.

\section{Disleksia}

Menurut Shaywitz, disleksia adalah gangguan membaca yang lebih mempengaruhi kemampuan proses bahasa daripada proses

sistem visual. (1996, para. 1). Karena mengganggu sistem proses bahasa, penderita mengalami kesulitan ketika harus mengartikan arti tulisan yang didapat dari sistem visual. Gangguan yang ada tidak berasal dari sistem visual penderita, melainkan sistem proses bahasa. Secara mendetil, disleksia mengganggu proses decoding (proses mengartikan sebuah kata menjadi bentuk-bentuk fonim). Meskipun begitu, penderita memiliki tingkat kecerdasan yang normal atau di atas rata-rata.

Disleksia sendiri terdiri dari beberapa sisi yang tidak semuanya didapati pada penderita disleksia, yaitu disleksia auditori, visual, dan auditori/visual. Ketiga sisi disleksia ini mengganggu sistem bahasa penderita dengan cara yang berbeda.

Menurut wawancara yang dilakukan kepada Suhadianto, S.Psi., M.Psi., sering kali orang tua di Indonesia baru mengeluhkan gangguan membaca anak pada usia 7-9 tahun. Hal ini disebabkan orang tua yang baru menyadari bahwa anak mereka tidak dapat mengikuti pelajaran yang dapat diikuti dengan mudah oleh anak-anak sebaya mereka. Namun menurut Shaywitz, intervensi gangguan belajar seharusnya sudah dilakukan sejak usia 5-6 tahun (Shaywitz, 2003, hal. 261). 


\section{Pembelajaran Orangtua Anak}

Dalam lingkungannya yang luas, seorang anak memiliki banyak sumber pembelajaran yang bisa ia dapatkan. Media pembelajaran buku, televise, internet, dan sekolah adalah contoh-contoh media yang dapat diakses oleh anak. Namun, partisipasi dari orang tua membeirkan pengaruh yang cukup signifikan bagi anak. Pada umumnya, dalam pembelajaran anak orang tua berperan untuk;

\section{Menjadi fasilitator media pembelajaran}

Seorang anak tidak akan bisa mengakses televisi ataupun internet tanpa adanya orang tua yang menjadi fasilitator. Orang tua bertugas untuk mendekatkan anak dengan media pembelajaran yang dibutuhkan oleh anak.

\section{Membangun pengalaman anak dalam}

\section{belajar.}

Yang dimaksud dengan membangun pengalaman belajar anak adalah membantu proses penyerapan ilmu anak. Contohnya ketika sedang membacakan buku, orang tua dapat menggunakan berbagai macam aksi agar anak lebih memahami cerita. Orang tua bisa membantu anak mengartikan tulisan, menanyakan pertanyaan yang berhubungan dengan cerita, ataupun mengulangi kata yang tidak familiar dengan anak secara perlahan (Robb, M.J., 2010).

Namun lebih dari itu, orang tua juga memberi efek yang lebih pada pembelajaran anak. Pada penelitian yang dilakukan oleh Micahel Benjamin Robb (2010), dilakukan eksperimen pada pembelajaran baca tulis anak dengan menggunakan media interaktif. Kelompok anak pertama diajak untuk menggunakan media interaktif tersebut sendirian. Sedangkan kelompok anak kedua didampingi oleh orang tua mereka masingmasing sambil menggunakan media interaktif. Hasilnya, anak yang belajar dengan bantuan orang tua akan memiliki kemampuan baca tulis yang lebih baik dibanding sendirian. Disimpulkan bahwa tingkat keterilibatan orang tua dalam pengaruh pembelajaran anak sangatlah berpengaruh.

Penelitian ini juga dilanjutkan dengan membandingkan media yang dipakai bersama orang tua anak. Media yang digunakan ialah media interaktif, media non-interaktif, dan media interaktif cetak. Meskipun ketiga jenis media menghasilkan tingkat pemahaman anak akan cerita yang bagus, ditulis bahwa tingkat keterlibatan orang tua berbanding lurus dengan tingkat pemahaman anak akan cerita. Pernyataan ini kemudian dilanjutkan dengan kesimpulan bahwa keberadaan orang 
tua pun sudah sangat cukup untuk membantu pembelajaran baca tulis anak.

Tingkat pemahaman cerita sendiri bisa diartikan dengan kemampuan decoding, kosa kata, dan kemampuan metacognitive (salah satu komponen utama kemampuan membaca) anak.

\section{Metode Belajar Baca Tulis Disleksia}

Menurut Shaywitz, secara garis besar pembelajaran disleksia dibagi menjadi dua tahap, yaitu akurasi (accuracy) dan kelancaran (fluency) membaca. Pada proses pembelajaran membaca dengan akurat, anak perlu belajar untuk mengerti bunyi fonem, pengejaan, kosakata, dan konsep dari alfabet. Pembelajaran multi sensori ialah cara yang tepat untuk mempelajari akurasi membaca (Shaywtiz, 2003, hal. 261-268)

Seperti yang sudah tertulis dalam data mengenai pembelajaran multi sensori, metode belajar baca tulis penderita disleksia akan mengajak anak untuk menggunakan berbagai indera. Secara mendasar, metode pembelajaran dapat dilakukan dengan;

\section{Menulis di sandbox}

Dengan menulis di sandbox, indera penglihatan, peraba, dan pendengar anak dilibatkan dalam pembelajaran. Metode ini dapat dilakukan dengan mengajak anak untuk menuliskan huruf yang dibacakan oleh orang tua.

\section{Air Writing}

Air writing atau menulis di udara dapat membantu anak untuk melatih muscle memory mereka. Metode ini dapat membantu anak untuk mengatasi kebingungan arah huruf seperti "b" dan "d." Sembari menulis dengan menggunakan huruf ke depan tubuh, ada baiknya bila anak dihimbau untuk membayangkan warna tulisan.

\section{Huruf Sandpaper}

Metode ini mengajak anak menggunakan indera perasa dengan menggunakan tekstur tulisan huruf yang berbeda dengan tekstur background. Alat peraga huruf bertekstur ini kemudian dapat digunakan dengan melatih anak membaca fonem huruf sambil meraba.

\section{Menyusun huruf}

Menyusun huruf dapat dilakukan dengan menggunakan alat peraga huruf magnetik. Pada metode ini, anak diajak untuk menyusun huruf yang disebutkan oleh orang tua. Alat peraga huruf magnetik ini dapat dibantu dengan warna. Contohnya, huruf konsonan dapat dibuat berwarna berbeda dengan huruf vokal, atau tiap suku kata berwarna berbeda dengan suku kata yang 
lain. Metode ini juga dapat dilakukan dengan memberikan pertanyaan kepada anak, lalu memintanya untuk menjawab pertanyaan dengan menggunakan alat peraga. Setelah berhasil menyusun jawabannya, anak akan diminta untuk membaca hasil jawabannya.

\section{Membaca, menyusun, dan menulis}

Metode ini dapat diaplikasikan pada pengajaran grup ataupun privat. Pada metode ini, kertas dengan tiga label "baca", "susun", dan "tulis" disediakan bagi anak. Selain itu, dibutuhkan juga kartu berisi contoh-contoh kata atau sight words, alfabet magnet, dan pensil. Pada label "baca", anak diminta untuk membaca dari kartu sight words. Pada label "susun", anak diminta untuk menyusun kata tersebut dengan alfabet magnet. Dan terakhir pada label "tulis", anak diminta untuk menuliskan kata.

\section{Taping out sounds}

Metode ini melibatkan sistem gerak motorik dan auditori untuk melatih anak memahami fonem. Ketika mengucapkan sebuah kata, anak diminta untuk memecah kata tersebuh menjadi fonem-fonem, kemudian membuat suara dengan jari setiap kali mereka mengucapkannya.

\section{Story Sticks}

Metode ini menuliskan beberapa pertanyaan mengenai sebuah cerita pada beberapa stik. Warna stik akan berbeda dengan stik yang lain berdasarkan jenis pertanyaannya. Sembari membaca cerita, anak akan diberikan stik dengan pertanyaan tertentu. Metode ini dibuat untuk membantu anak agar dapat memahami isi teks bacaan dengan baik.

\section{Membaca Bersama}

Ketika sedang membaca bersama, anak dapat menggunakan indera penglihatan dan pendengaran di saat bersamaan. Metode ini dapat digunakan secara interaktif oleh orang tua dan anak. Contohnya, orang tua dapat membantu menggaris bawahi kata-kata yang mungkin belum familiar bagi anak (Morin, n.d.).

Setelah menguasai akurasi bacaan, pembelajaran kelancaran (fluency) membaca juga perlu dilakukan. Menurut Shaywitz, setelah melakukan pelatihan awareness akan fonem huruf, pelatihan kelancaran dan akurasi perlu dilakukan. Kelancaran membaca dapat dicapai apabila akurasi membaca sudah dikuasai oleh anak. Karena itu, anak perlu berlatih. Untuk berlatih, anak dapat membaca teks yang sama paling tidak empat kali sehari (tidak harus dilakukan pada satu sesi belajar). Pembelajaran kelancaran 
membaca ini dapat dilakukan dengan membaca sebuah teks bersama berulangulang kali. Caranya, anak dan orang tua membaca sebuah teks yang sama 2 hingga 3 kali. Kemudian, anak mencoba membaca teks tersebut sendirian. Teks yang dibacakan bisa dimulai dengan topik yang menarik bagi anak, kemudian dilanjutkan pada teks fiksi, non fiksi, puisi, ataupun skrip drama. Sebuah metode Metode ini akan membangun kelancaran membaca anak dengan baik (Shaywitz, 2003, hal. 268-276).

\section{KONSEP PERANCANGAN}

\section{Strategi Kreatif Pembelajaran}

Berangkat dari topik utama belajar baca tulis bagi disleksia, perancangan ini mengambil tema traveling bagi anak. Dalam perancangan ini, akan dibuat sebuah kotak yang berisikan sebuah buku panduan bagi orang tua, sebuah buku belajar bagi anak, dan beberapa permainan interaktif.

Kotak yang dirancang akan dibuat seolah terlihat seperti koper dari luar. Berdasarkan tema traveling, maka ilustrasi yang dibuat dalam buku anak akan dibuat berdasarkan dua tempat, yaitu gunung dan pantai. Kedua tempat ini kemudian menjadi dasar soal latihan yang akan dikerjakan bersama orang tua dan anak.
Dengan menggunakan tema traveling, anak akan tertarik untuk membawa kotak kemana pun ia pergi. Dengan menggunakan tema gunung dan pantai yang tidak spesifik, orang tua dapat memberikan sentuhan personal yang sesuai dengan pengalaman anak. Contohnya, orang tua dapat menggunakan ilustrasi pantai dan menyebutnya sebagai pantai yang pernah mereka kunjungi berdua. Dengan begitu, anak memiliki ingatan yang kuat tentang kondisi yang digunakan untuk belajar.

Berangkat dari tema traveling, buku interaktif perancangan akan dibuat berjudul "Belajar Membaca Sambil Jalan-jalan" dengan sub-tema "Panduan belajar baca tulis orang tua untuk anak Disleksia." Kata "Jalan-jalan" akan ditekankan pada penulisan judul sehingga media perancangan akan terkesan lebih menyenangkan dan santai.mBerisikan beberapa obyek, berikut ialah konten dari perancangan ini;

\section{Buku dan Video panduan orang tua}

\section{Pengertian disleksia}

Bab ini berisi penjelasan singkat mengenai apa itu disleksia, penyebab disleksia, hingga efek yang diakibatkan oleh disleksia. Selain itu, sedikit informasi mengenai bagaimana memberikan dorongan mental kepada anak penderita juga dituliskan. 


\section{Cara menggunakan media perancangan}

Bab ini berisi cara menggunakan setiap permainan interaktif yang disediakan dalam perancangan. Selain itu, petunjuk mengenai urutan pemakaian serta cara memberikan sentuhan personalisasi pada perancangan juga dituliskan. Panduan ini berisi bagaimana menggunakan setiap permainan dan bagaimana mengkombinasikannya agar anak tidak merasa cepat bosan.

\section{Buku belajar anak}

\section{Alfabet dengan tekstur}

Media ini menyediakan seluruh alfabet dan angka 1 hingga 0 . Untuk membantu anak memahami alfabet dengan mudah, warna huruf vokal, warna huruf konsonan, dan warna angka akan dibuat berbeda.

\section{Ilustrasi traveling}

Pada buku ini, dibuat 2 ilustrasi yang menggambarkan pantai dan gunung seperti konsep traveling. Fungsi dari ilustrasi ini ialah sebagai bentuk buku interaktif hidden objects dimana anak dapat mencari-cari obyek dalam ilustrasi tersebut.

\section{Teks latihan membaca}

Teks ini berfungsi sebagai latihan kelancaran (fluency) membaca anak. Berbagai teks pendek seperti kisah anak-anak Kancil yang
Cerdik ataupun dongen tradisional dituliskan pada bab ini.

\section{Permainan Interaktif}

\section{Sandbox}

Sandbox berfungsi sebagai media tulis anak. Dibutuhkan sebuah kotak yang cukup besaru untuk dapat menampung pasir agar bisa ditulis oleh anak.

\section{Alfabet magnetik}

Sama seperti media sandpaper, media ini akan membedakan warna huruf vokal, huruf konsonan, dan angka.

\section{Flashcard kata}

Flashcard kata akan dibagi menjadi 3 kategori, yaitu obyek pantai dan obyek gunung. Tiap kartu akan berisikan berbagai obyek sederhana sesuai kategorinya. Contohnya flashcard pantai akan berisikan obyek-obyek yang ada di pantai seperti kaca mata renang. Satu sisi kartu akan menggambarkan ilustrasi obyek, sedangkan satu sisinya akan menggambarkan tulisan obyek secara lisan.

\section{Kartu "Baca, Susun, Tulis" dan spidol}

Kartu ini dibuat sedemikian rupa hingga dapat dengan mudah ditulis oleh spidol nonpermanen. Tujuannya, kartu ini dapat dipakai 
berulang kali untuk pembelajaran yang panjang.

\section{Metode Pembelajaran \& Penyajian Konten}

Metode pembelajaran dibagi menjadi dua, yaitu akurasi (accuracy) dan kelancaran (fluency). Pada pembelajaran akurasi, terdapat beberapa metode yang dapat dilakukan oleh orang tua dan anak penderita;

\section{Memahami bentuk huruf dengan sandpaper.}

Untuk membantu anak semakin memahami bentukan huruf, anak akan dihimbau untuk menyentuh tiap huruf bertekstur di buku dan menyebutkan bunyi fonem huruf tersebut. Contohnya, pada huruf $\mathrm{W}$ anak harus bisa menyebut fonem /we/. Huruf-huruf bertekstur ini pun akan dibagi menjadi dua warna, yaitu huruf konsonan dan huruf fokal.

\section{Memahami kombinasi huruf dengan alfabet magnetik atau sandbox.}

Dengan menggunakan gabungan hurufhuruf, orang tua dapat mengajarkan anak bunyi fonem dari gabungan huruf vokal dan huruf konsonan. Contohnya gabungan dari huruf magnetik B dan A akan berbunyi /ba/. Untuk mengajarkan bunyi fonem ini, orang tua dapat menuliskan kombinasi huruf di sandbox ataupun memberikan susunan alfabet magnetik.

\section{Memahami konsep kata dengan Flash Cards dan ilustrasi hidden objects.}

Permainan ini menggunakan gabungan dari kedua media. Pertama-tama, anak mengambil kartu flashcard secara acak. Kemudian tanpa memperlihatkan ilustrasi obyek dibaliknya, anak diminta untuk membaca tulisan nama obyek. Ketika berhasil membaca nama obyek dengan baik, anak boleh melihat ilustrasi obyek dibaliknya. Setelah itu, anak dapat mencari obyek tersebut pada ilustrasi hidden objects di buku anak. Kegiatan ini kemudian terus diulang hingga anak dapat membaca semua flashcard.

\section{Menulis dengan sandbox.}

Orang tua dapat menghimbau anak dengan meminta anak menulis ulang sebuah kata di sandbox. Kata yang ditulis oleh anak dapat diambil dari flashcard ataupun dari tulisan tangan orang tua sendiri.

Membaca, menyusun, dan menulis.

Dengan menggunakan kartu read it, build it, write it, anak diminta membaca sebuah kata yang diberikan oleh orang tua secara lantang. Kemudian anak dihimbau untuk menyusun 
kata tersebut dengan alfabet magnetik, hingga akhirnya menulis ulang dengan spidol.

Setelah anak berhasil menguasai pelatihan akurasi (accuracy), anak harus melakukan pelatihan kelancaran (fluency). Pelatihan kelancaran dapat dilakukan dengan membaca ulang sebuah teks secara bersamaan dengan orang tua. Pembelajaran ini bisa dilakukan dengan membacakan sebuah paragraf pada anak sekali atau dua kali. Selanjutnya, orang tua dan anak akan membaca secara bersamaan. Ketika selesai membaca, orang tua dapat memberikan pertanyaan pada anak untuk menguji pemahaman anak mengenai isi teks.

Pada pembelajaran yang lebih variatif, orang tua dan anak dapat saling membagi peran dialog. Dengan membagi peran dan membaca dialog secara lantang, orang tua dapat memberikan bantuan pemahaman kepada anak. Skrip dialog memberikan pengaruh yang baik bagi pembelajaran membaca anak, terlebih lagi apabila orang tua memberikan penjelasan dengan intonasi yang sesuai dengan sifat karakter tokoh.

\section{HASIL PERANCANGAN}

Buku Latihan Anak
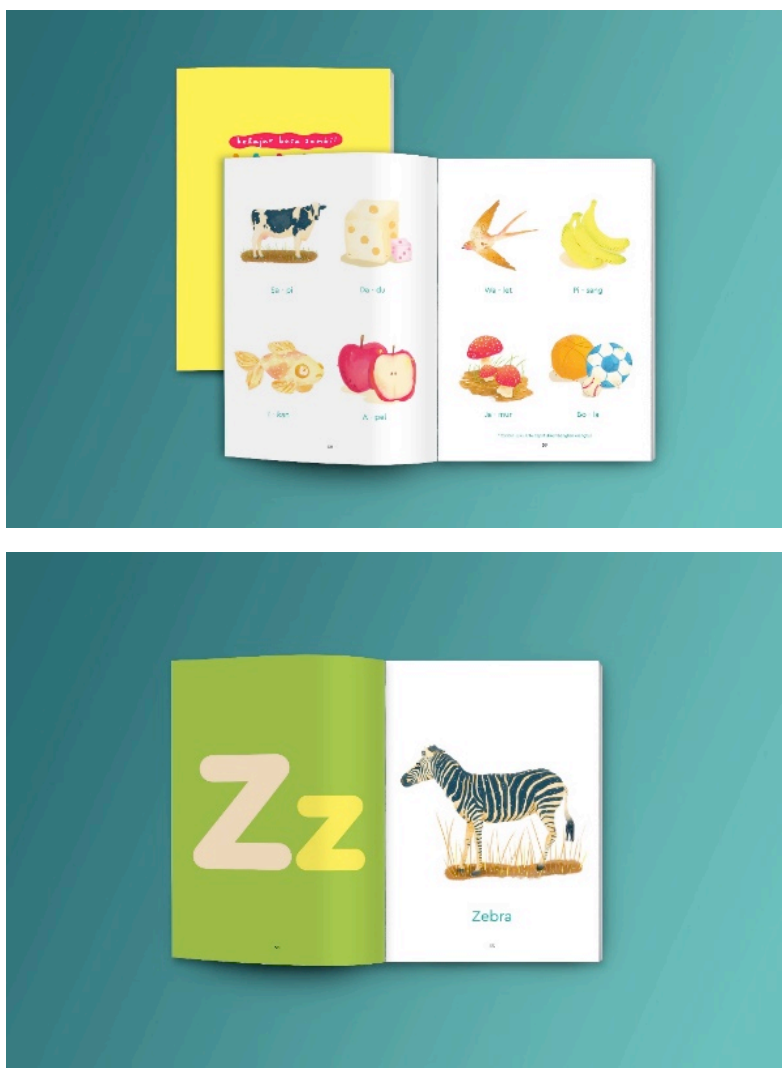

Gambar 2 Mockup buku belajar anak 1

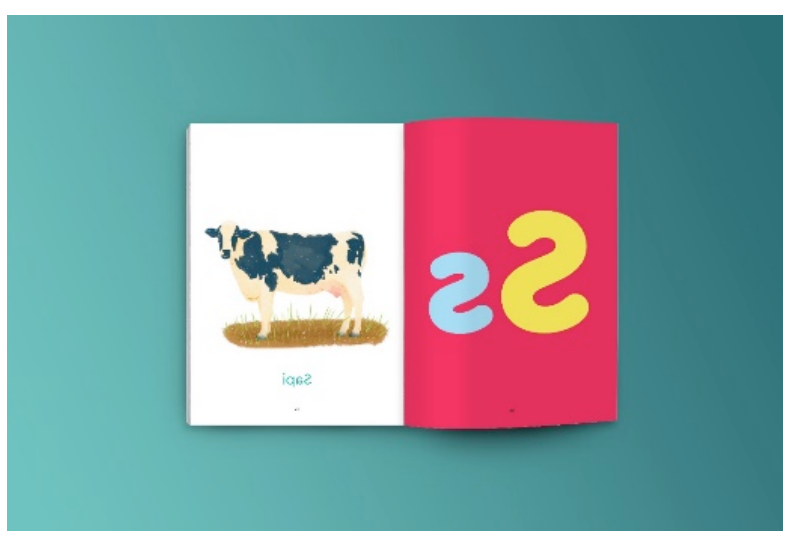

Gambar 3 Mockup buku belajar anak 2 


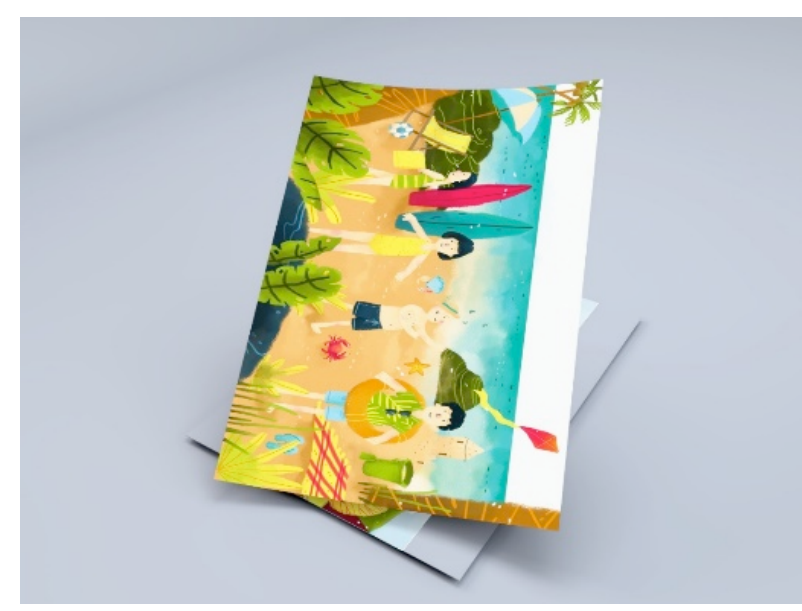

Gambar 4 Ilustrasi hidden object pantai

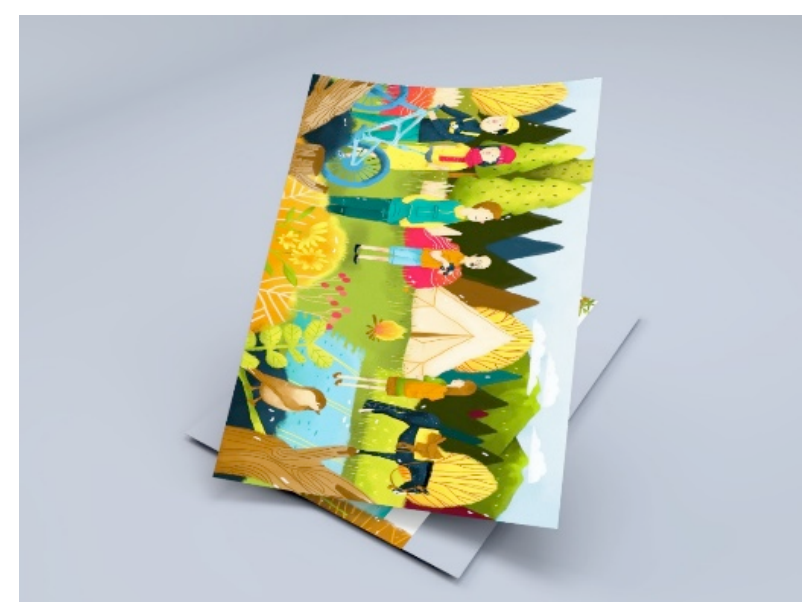

Gambar 5 Ilustrasi hidden object gunung

\section{Buku Panduan Orangtua}

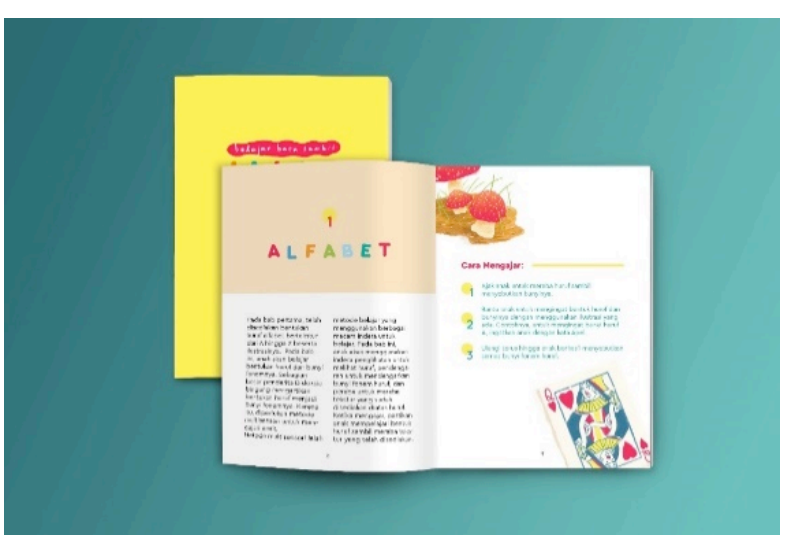

Gambar 6 Mockup buku panduan orangtua 1

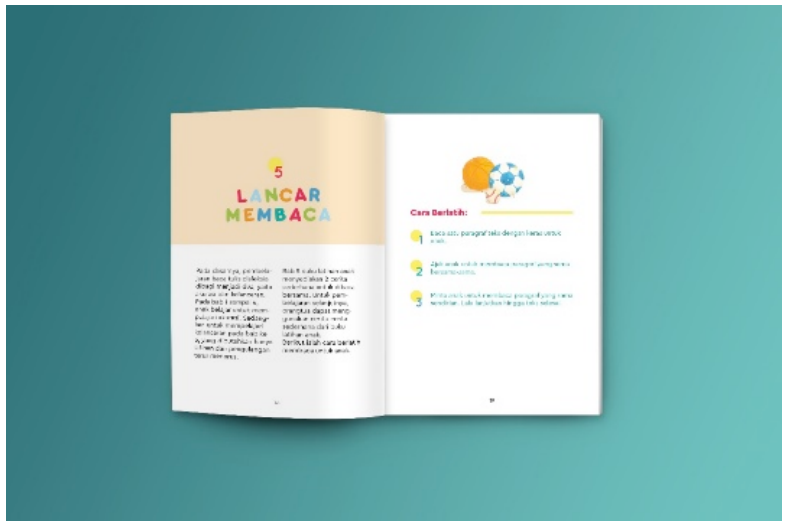

Gambar 7 Mockup buku panduan orangtua 2

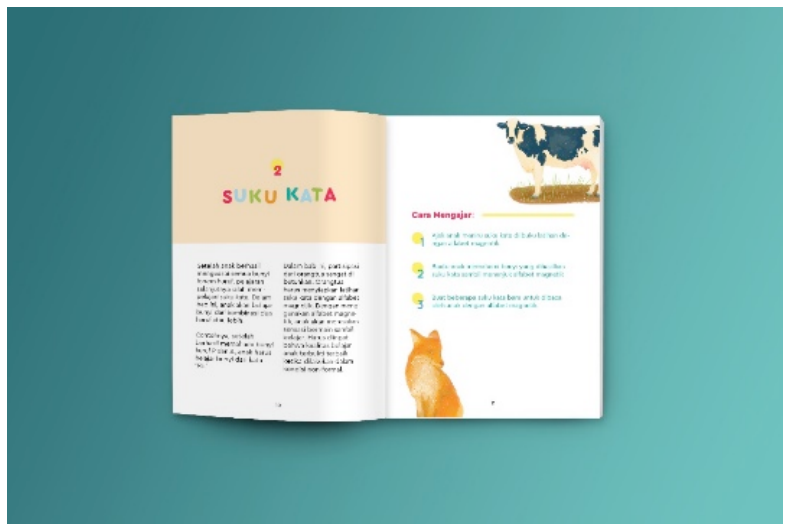

Gambar 8 Mockup buku panduan orangtua 3

\section{Video Panduan Orangtua}

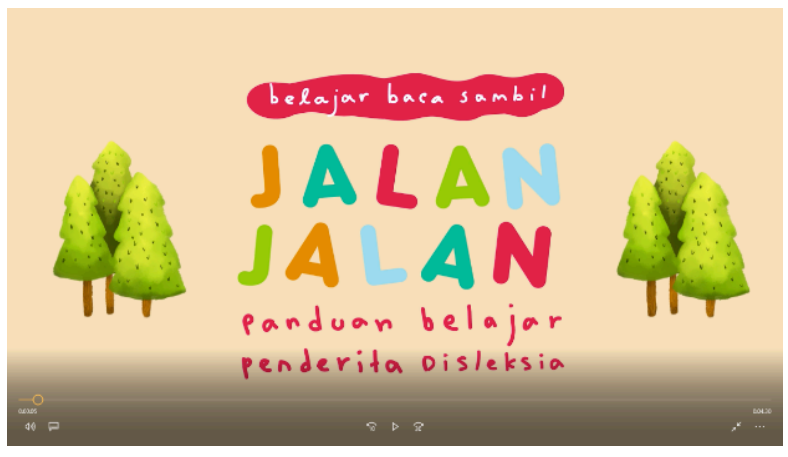

Gambar 9 Screen capture video panduan orangtua 1 


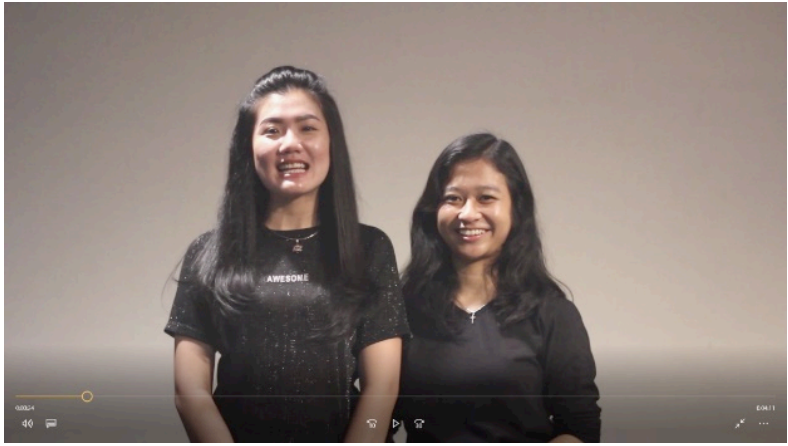

Gambar 10 Screen capture video panduan orangtua 2

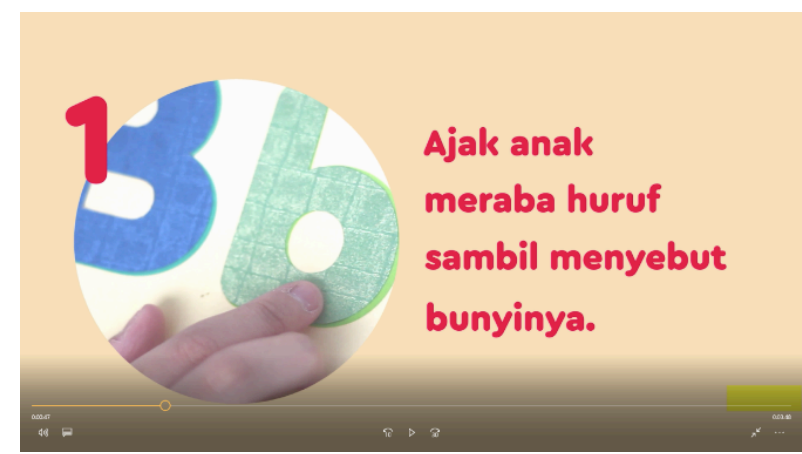

Gambar 11 Screen capture video panduan orangtua 3

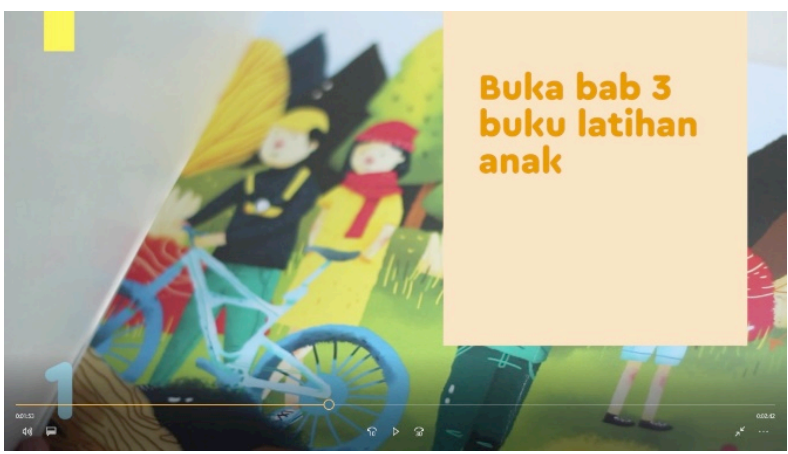

Gambar 12 Screen capture video panduan orangtua 4

\section{Perlengkapan Interaktif}

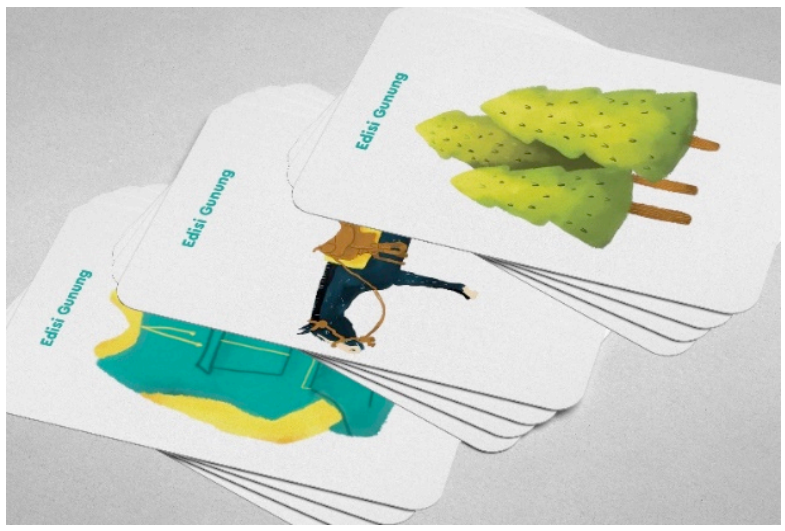

Gambar 13 Mockup Flashcard 1

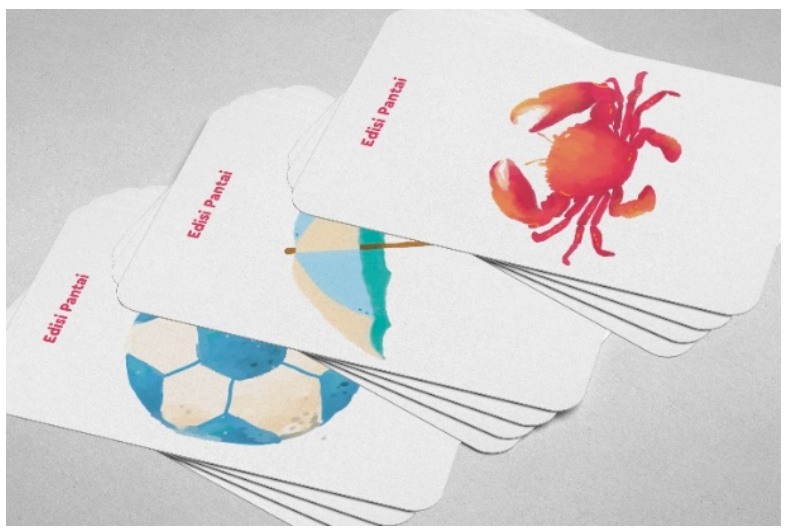

Gambar 14 Gambar 15. Mockup Flashcard 2

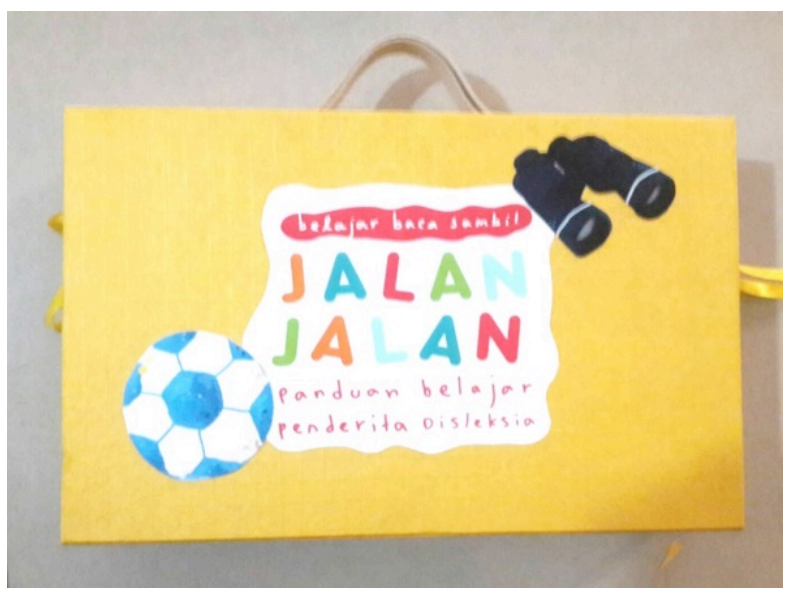




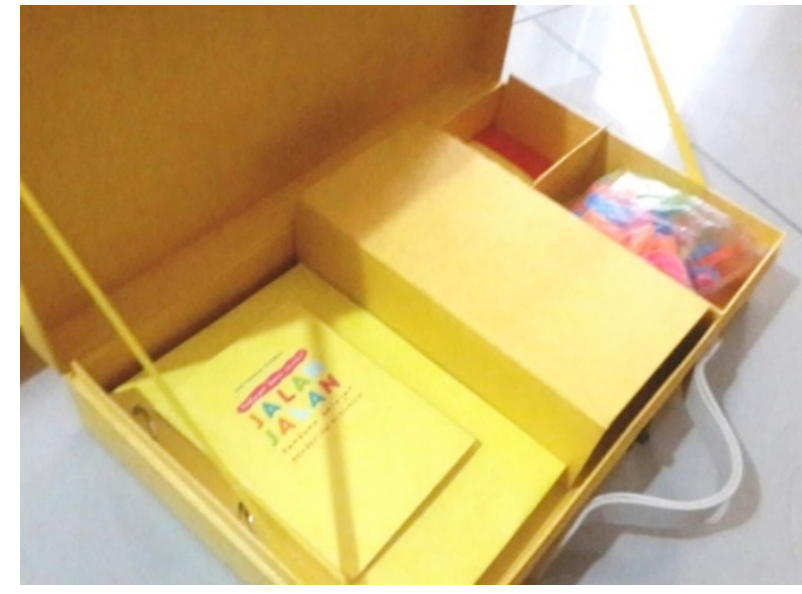

Gambar 15 Packaging perancangan 2

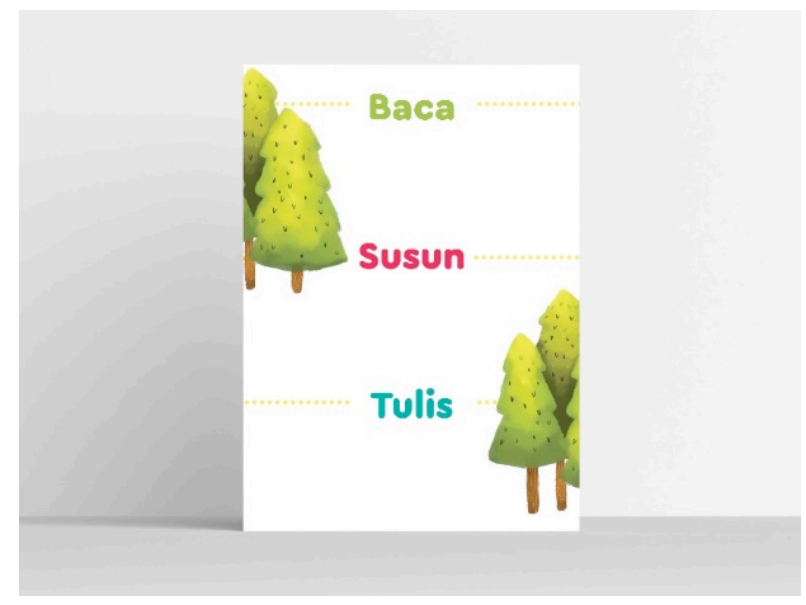

Gambar 16 Kartu baca susun tulis

\section{KESIMPULAN DAN SARAN}

Penderita Disleksia membutuhkan pembelajaran dengan metode multi-sensori, dimana indera yang dipakai untuk belajar lebih dari satu. Karenanya, perancangan ini dibuat dengan berbagai perlengkapan yang dapat merangsang indera anak. Selain itu, pembelajaran dalam kondisi non-formal selalu menghasilkan hasil yang maksimal. Dengan mengutamakan kesan fun dan personal, perancangan ini diharapkan dapat membantu penderita Disleksia.
Untuk perancangan lebih lanjut, ada baiknya bila perancangan yang dibuat menyediakan perlengkapan yang lebih lengkap. Tidak hanya merangsang indera anak dengan tekstur, diharapkan perancangan ke depan dapat melibatkan lagu dan permainan interaktif lainnya.

Dalam pengembangan buku latihan anak, sebaiknya permainan yang dirancang lebih dari satu. Lebih jauh lagi, ada baiknya bila permainan yang dirancang dapat dipersonifikasi sesuai dengan kebutuhan anak. Contohnya, permainan kartu yang sudah dibuat akan menjadi jauh lebih baik apabila obyeknya dapat diganti-ganti.

Karena dirancang untuk menjadi sebuah paket pembelajaran yang menyenangkan, media ini tidak dibuat dengan dasar timeline. Padahal dengan adanya timeline, orangtua dapat lebih mudah mengukur hasil evaluasi anak. Sebaiknya perancangan pembelajaran baca tulis Disleksia selanjutnya dibuat berdasarkan timeline waktu agar praktis dipakai oleh orangtua dan anak. 


\section{DAFTAR PUSTAKA}

[1] Bodmer, G. R. (1992). Approaching the illustrated text. In G.E. Sadler (Ed.), Teaching children's literature: Issues, pedagogy, resources (pp. 72- 79). NY: The Modern Language Association of America.

[2] Broudy, H.S. (1977). How basic is aesthetic education? Language Arts, 54, 631-637.

[3] Craft, D. (2016). Dyslexia: How Do I Teach This Child? Diannecraft. Retrieved March 21, 2017, from http://www.diannecraft.org

[4] Dipa, A. (2012). Dyslexic Kids Can Develop Normally, With Help. The Jakarta Post. Retrieved November 16, 2016, from http://www.thejakartapost.com

[5] Fang, Z. (1996). Reading Horizons. The Berkeley Electronic Press. Retrieved Maret 12, 2017, from http://scholarworks.wmich.edu

[6] Ginsburg, K. (2017). The Importance of Play in Promoting Healthy Child Development and Maintaining Strong Parent-Child Bonds. American Academy of Pediatrics. Retrieved March 20, 2017, from

http://pediatrics.aappublications.org

[7] Gordon, B., Gordon, M. (2010). Graphic Design Pocket Essentials. Ilex Press Limited: United Kingdom.

[8] Haley, A. (n.d.) It's about Legibility. Monotype Imaging Inc. Retrieved March 15, 2017, from http://fonts.com

[9] Haley, A. (n.d.) Type Classifications. Monotype Imaging Inc. Retrieved March 15, 2017, from http://fonts.com

[10] Hamalik, O. (2003) Proses Belajar Mengajar. (Jakarta: Bumi Aksara) cet. Ke-2. hal 27

[11] Jenkins, J. (2016). The yale center for dyslexia \& creativity: 10 things parents need to know to help a struggling reader.
Yale University. Retrieved November 16, 2016, from http://www.dyslexia.yale.edu

[12] Latief. (2010, Agustus 3). Belajar asyik ala anak-anak disleksia. Kompas Cyber Media. Retrieved October 25, 2016, from http://www.edukasi.kompas.com

[13] Mangunsong, F. (2009). Psikologi dan Pendidikan Anak Berkebutuhan Khusus. Depok: LPSP3 UI.

[14] Maulidiya, P. (2016, October 29). Atasi gangguan disleksia pada anak, ini yang dilakukan dinas pendidikan kota Surabaya. Tribun News. Surya. Retrieved October 25, 2016, from http://www.surabaya.tribunnews.com

[15] Morin, A. (n.d.) 8 Multisensory Techniques for Teaching Reading. Understood. Retrieved March 21, 2017, from http://understood.org

[16] Oey, F.W. (2013). Perancangan buku interaktif pengenalan dan pelestarian sugar glider di Indonesia bagi anak 7-12 tahun. (TA No. 06132365/ARS/2013). Unpublished undergraduate thesis, Universitas Kristen Petra, Surabaya.

[17] Permanasari, I. (2010). Mereka (Tetap) Anak Pintar...Kompas Cyber Media. Retrieved October 25, 2016, from http://nasional.kompas.com/

[18] Pertiwi, P. (2016). Disleksia, Bukan Berarti Kamu Tidak Hebat. Lexipal Indonesia. Retrieved October 25, 2016, from http://lexipalindonesia.com/

[19] Praveen, A. V. (2016). What is Multisensory Teaching Techniuqes? Lexicon Reading. Retrieved March 3, 2017, from http://lexiconreadingcenter.org

[20] Shaywitz, S. (1996). The yale center for dyslexia \& creativity: Dyslexia. Yale University. Retrieved October 25, 2016, from http://www.dyslexia.yale.edu

[21] Shaywitz, S. (2003). Overcoming Dyslexia. New York: Random House Inc. 
[22] Shipley, D. (1998). Empowering Children. Scaraborough: International Thomson Publishing.

[23] Syahfauziah, S. J. (2016). Dyslexia corner pertama di Indonesia dibuka di surabaya. Tempo. Retrieved October 25, 2016, from http://tempo.co

[24] Segrin, C. Flora, J. (2005). Family Communication. New jersey: Lawrence Erlbaum Associates.

[25] Sekaran, U. (2006). Metodologi Penelitian untuk Bisnis. Jakarta: Salemba Empat

[26] Strizver, I. (n.d.). Typography for Children. Monotype Imaging Inc. Retrieved March 18, 2017, from http://fonts.com

[27] Stuart, A. (2007). When Should Kids Learn to Read, Write, and Do Math? Webmd. Retrieved March 3, 2017, from http://webmd.com

[28] UC Berkeley (n.d.) What is Learning? UC Berkeley. Retrieved March 7, 2017, from http://teaching.berkeley.edu

[29] Wier, A. (n.d). Multi-Sensory Interactive Books. Retrieved March 3, 2017, from http://infogr.am

[30] Wijaya, P.Y. (2010). Tipografi dalam Desain Komunikasi Visual. Retrieved March 15, 2017, from http://puslit2.petra.ac.id

[31] Ibu dan Balita (2011). Psikologi Anak dan Peran Ayah agar Anak Secerdas Einstein. Layanan Ibu dan Balita. Retrieved March 7, 2017, from http://ibudanbalita.com 